\title{
Stomatal and non-stomatal fluxes of ozone to a northern mixed hardwood forest
}

\author{
By ALAN HOGG ${ }^{1 *}$, JOHAN UDDLING ${ }^{2}$, DAVID ELLSWORTH ${ }^{2 \dagger}$, MARY ANNE \\ CARROLL ${ }^{1,3}$, SHELLEY PRESSLEY ${ }^{4}$, BRIAN LAMB ${ }^{4}$ and CHRISTOPH VOGEL ${ }^{5}$, ${ }^{1}$ Department \\ of Atmospheric, Oceanic, and Space Sciences, University of Michigan, Ann Arbor, MI 48109, USA; ${ }^{2}$ School of Natural \\ Resources and Environment, University of Michigan, Ann Arbor, MI 48109, USA; ${ }^{3}$ Department of Chemistry, \\ University of Michigan, Ann Arbor, MI 48109, USA; ${ }^{4}$ Department of Civil and Environmental Engineering, \\ Washington State University, Pullman, WA 99164, USA; ${ }^{5}$ University of Michigan Biological Station, University of \\ Michigan, Pellston, MI 49769, USA
}

(Manuscript received 30 April 2006; in final form 28 December 2006)

\begin{abstract}
Measurements of ozone, sensible heat, and latent heat fluxes and plant physiological parameters were made at a northern mixed hardwood forest located at the University of Michigan Biological Station in northern Michigan from June 27 to September 28, 2002. These measurements were used to calculate total ozone flux and partitioning between stomatal and non-stomatal sinks. Total ozone flux varied diurnally with maximum values reaching $100 \mu \mathrm{mol} \mathrm{m}^{-2} \mathrm{~h}^{-1}$ at midday and minimums at or near zero at night. Mean daytime canopy conductance was $0.5 \mathrm{~mol} \mathrm{~m}^{-2} \mathrm{~s}^{-1}$. During daytime, non-stomatal ozone conductance accounted for as much as 66\% of canopy conductance, with the non-stomatal sink representing $63 \%$ of the ozone flux. Stomatal conductance showed expected patterns of behaviour with respect to photosynthetic photon flux density (PPFD) and vapour pressure defecit (VPD). Non-stomatal conductance for ozone increased monotonically with increasing PPFD, increased with temperature $(T)$ before falling off again at high $T$, and behaved similarly for VPD. Day-time non-stomatal ozone sinks are large and vary with time and environmental drivers, particularly PPFD and $T$. This information is crucial to deriving mechanistic models that can simulate ozone uptake by different vegetation types.
\end{abstract}

\section{Introduction}

The impact of tropospheric ozone on forests is a major concern in North America and Europe (e.g., Skärby et al., 1998; Karnosky et al., 2003; Matyssek and Sandermann, 2003; Percy et al., 2003; Felzer et al., 2004). At present, approximately one quarter of the area of global forests is exposed to peak concentrations exceeding $60 \mathrm{nmol} \mathrm{mol}^{-1}$ (Fowler et al., 2001). Effects of ozone on the metabolism of trees are typically mediated by a dose-dependent effect related to uptake through the stomata (Reich et al., 1987), yet ozone also causes important changes in plant surface properties such as increased production and amount of epicuticular wax with a less crystalline structure, causing increased wettability and stomatal occlusion (e.g. Karnosky et al., 1999; Karnosky et al., 2002; Percy et al., 2002; Karnosky et al., 2003).

\footnotetext{
*Corresponding author.

e-mail: alanhogg@umich.edu

${ }^{\dagger}$ Current address: Centre for Plant Science, University of Western Sydney, Locked Bag 1797, Penrith South DC, NSW 1797, Australia. DOI: $10.1111 /$ j.1600-0889.2007.00269.x
}

Given the importance of uptake through the stomata, efforts have been made to relate the effects of ozone exposure to stomatal fluxes rather than ambient concentration (Reich et al., 1987; Karlsson et al., 2004; Uddling et al., 2004). However, accurate estimations of ozone concentrations as well as separation between stomatal and non-stomatal fluxes are needed for accurate ozone risk assessment and the generation of effective emission abatement strategies. It is assumed in most large-scale ozone deposition models (e.g. Zeller and Nikolov, 2000; Zhang et al., 2002b; Massman, 2004) that the non-stomatal sink is a passive receptor of ozone, with constant and low affinity for ozone. However, laboratory studies as well as studies of ecosystem fluxes suggest that the non-stomatal conductance for ozone $\left(g_{\mathrm{ns}}\right)$ is neither low nor constant. Field studies of forests that have partitioned ozone fluxes into stomatal and non-stomatal components show that the non-stomatal component is $30-70 \%$ of the total flux, even for dry canopies during daytime (Coe et al., 1995; Granat and Richter, 1995; Mikkelsen et al., 2000; Zeller and Nikolov, 2000; Mikkelsen and Ro-Poulsen, 2002; Kurpius and Goldstein, 2003; Altimir et al., 2004; Cieslik, 2004; Gerosa et al., 2005). 
Furthermore, several studies show that $g_{\text {ns }}$ varies diurnally (e.g. Coe et al., 1995; Granat and Richter, 1995; Gerosa et al., 2005).

This variation in $g_{\mathrm{ns}}$ has been attributed to a number of drivers (light, temperature, wind speed and relative humidity) and processes (surface reactions, thermal decomposition and gas-phase chemistry). Rondón (1993) hypothesizes that $g_{\mathrm{ns}}$ is governed by a light-driven process that takes place on the leaf surface. The dependence of $g_{\mathrm{ns}}$ on temperature has been attributed to thermal decomposition on the leaf surface (Fowler et al., 1999; Fowler et al., 2001) and gas-phase chemistry involving biogenically emitted hydrocarbons (Goldstein et al., 2004; Kurpius and Goldstein, 2003). Wet surfaces have a higher affinity for ozone (e.g. Grantz et al., 1995; Pleijel et al., 1995), and some studies show $g_{\text {ns }}$ increasing at high relative humidity (Zhang et al., 2002a; Altimir et al., 2004; Altimir et al., 2005). Wind speed has also been found to have a positive effect on $g_{\text {ns }}$ (Lamaud et al., 2002; Zhang et al., 2002a).

Quantifying the flux of ozone and characterizing its behaviour and partitioning under different environmental conditions allows the extent of canopy stomatal ozone uptake to begin to be characterized. Building upon this, the amount of deposited ozone that is reacting with living plant biomass can be determined, with the ultimate goal of assessing the extent to which atmospheric ozone damages a forest ecosystem. In this study the fluxes of ozone, sensible heat and latent heat were measured over a northern mixed hardwood forest. Combining these measurements with gas transfer theory allowed the partitioning of stomatal and non-stomatal ozone fluxes to be determined. For summer 2002, the following questions were addressed: (1) How does ozone flux and $g_{\text {ns }}$ vary diurnally? (2) How is ozone flux partitioned between stomatal and non-stomatal sinks? (3) How do environmental drivers influence $g_{\text {ns }}$ and the flux of ozone?

\section{Experiment}

\subsection{Site description}

Measurements were made from June 27 to September 28, 2002, at the PROPHET site located at the University of Michigan Biological Station (UMBS) in northern Michigan, $45^{\circ} 30^{\prime} \mathrm{N}$, $84^{\circ} 42^{\prime} \mathrm{W}$, elevation $238 \mathrm{~m}$. This ecosystem is a 'mixed' or 'transition' forest consisting predominantly of bigtooth aspen (Populus grandidentata), but also with significant white pine, red oak, red maple and paper birch. The canopy height is on average $22 \mathrm{~m}$, with a leaf area index of 4 (Curtis et al., 2005) and an overstory age of approximately $80 \mathrm{yr}$. Within $1 \mathrm{~km}$ distance of the site in any direction, there is a maximum change in elevation of $20 \mathrm{~m}$, making the fetch relatively flat. The closest significant sources of pollution are Chicago (over $400 \mathrm{~km}$ to the southwest, 2000 metropolitan area population 9157540$)$, Detroit $(\sim 350 \mathrm{~km}$ to the southeast, 2000 metropolitan area population 5456428 ), (U. S. Census Bureau, 2001), Toronto, Ontario (over 400 km to the east-southeast, 2001 metropolitan area population 4682
897), and Sault St. Marie, Ontario ( $~ 130 \mathrm{~km}$ to the north, 2001 metropolitan area population 78 908) (Statistics Canada, 2002). The predominant flow regimes in the northern regions of the Michigan lower peninsula during summer are northwesterly and southwesterly (Moody and Samson, 1989). Without significant sources of pollution to the north, regional background ozone mixing ratios approach $25 \mathrm{nmol} \mathrm{mol}{ }^{-1}$ during periods of northwesterly flow (Thornberry et al., 2001). In contrast, periods of southwesterly flow bring much more polluted air with ambient ozone levels typically ranging from 40 to $80 \mathrm{nmol} \mathrm{mol}^{-1}$ with occasional excursions to $100 \mathrm{nmol} \mathrm{mol}^{-1}$. Mean temperature for the measurement period was $20^{\circ} \mathrm{C}$ (average maximum: $25^{\circ} \mathrm{C}$, average minimum: $15^{\circ} \mathrm{C}$ ) and rainfall was $91 \mathrm{~mm}$ in July, $134 \mathrm{~mm}$ in August, and $45 \mathrm{~mm}$ in September. More detailed descriptions of the site can be found in Carroll et al. (2001) and in Curtis et al. (2005).

\subsection{Instrumental methods}

Above-canopy fluxes of ozone were measured from the $35 \mathrm{~m}$ PROPHET tower. The ozone sample inlet and sonic anemometer were located $33 \mathrm{~m}$ above ground and the air sample was transported to the detector via a $40 \mathrm{~m}$ length of 5/8-in. Teflon tubing. The residence time from sample inlet to the detector in the laboratory at the base of the tower was typically less than $25 \mathrm{~s}$. Wind speed and direction (Wind Monitor-RE, R. M. Young Company, USA), pressure (Barometric Pressure Sensor Model 61201, R. M. Young Company, USA), temperature and relative humidity (MP100, Rotronics Instrument Corp, USA) are measured continuously at the top of the PROPHET tower (Carroll et al., 2001). An open-path infrared gas analyzer (IRGA) (Auble and Meyers, 1992) was co-located with the sonic anemometer (Kconfiguration, ATI, USA) to measure water and $\mathrm{CO}_{2}$ concentration (Pressley et al., 2005). Photosynthetic photon flux density (PPFD) (LI-190SZ, Li-Cor, USA) was measured on the adjacent Ameriflux tower (Schmid et al., 2003), which is located $132 \mathrm{~m}$ north-northeast of the PROPHET tower.

Ozone was measured using the University of Michigan Multichannel Chemiluminescence Instrument (UMMCI), a custom-built chemiluminescence detector (e.g. Ridley, et al., 1992), illustrated in Fig. 1. The detector consists of a gold-plated 316 stainless-steel reaction vessel $\left(\mathrm{RV}, 17 \mathrm{~cm}^{3}\right.$, maintained at $35^{\circ} \mathrm{C}$, design by B. A. Ridley, Ridley, et al., 1992), a red-sensitive Hamamatsu R1333 photomultiplier tube (PMT, operated at $5{ }^{\circ} \mathrm{C}$ ), and zeroing volume ( $\mathrm{ZV}$, maintained at $100{ }^{\circ} \mathrm{C}$ ) containing $0.5 \% \mathrm{Pd}$ on $\mathrm{Al}$ ozone destruction catalyst (Degussa Metals Corp.).

Pure NO reagent gas was premixed with ambient air immediately before entering the highly reflective, conical RV, which was coupled to the PMT through a red cutoff filter (transmitting $\lambda>$ $600 \mathrm{~nm}$ ) and a $\sim 1 \mathrm{~cm}$ thick Pyrex thermopane window. Ambient ozone mixing ratios were determined via measurement of the light emitted by excited state $\mathrm{NO}_{2}$ molecules generated during 


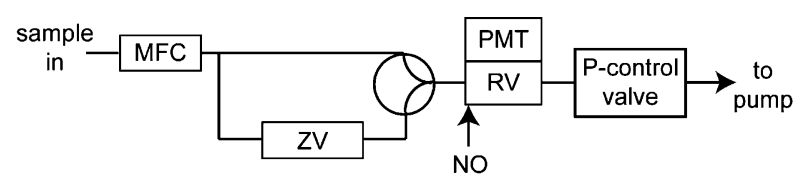

Fig. 1. Schematic of the ozone chemiluminescence detector used for ozone flux measurements in the study. Sample flow enters the instrument at sample in and is controlled by a mass flow controller (MFC). When the instrument is in measure mode, flow proceeds through a three-way valve to the reaction vessel (RV), where excess $\mathrm{NO}$ is added to convert $\mathrm{O}_{3}$ to $\mathrm{NO}_{2}$. A portion of the $\mathrm{NO}_{2}$ that is created is in an excited state, and as it de-excites, a photon is emitted and is counted by the photomultiplier tube (PMT). When the instrument is in zero mode, the flow is diverted through a zero volume (ZV) filled with $0.5 \% \mathrm{Pd}$ on $\mathrm{Al}$ ozone destruction catalyst. Reaction vessel pressure is controlled between the reaction vessel and the pump by a pressure control valve.

the $\mathrm{NO}-\mathrm{O}_{3}$ chemiluminescent reaction (Clough and Thrush, 1967; Clyne and Stedman, 1967):

$\mathrm{NO}+\mathrm{O}_{3} \rightarrow \mathrm{NO}_{2}+\mathrm{O}_{2}$
$\mathrm{NO}+\mathrm{O}_{3} \rightarrow \mathrm{NO}_{2}^{*}+\mathrm{O}_{2}$
The calibrator was connected to the instrument sample inlet, generating ozone mixing ratios of $0-120 \mathrm{nmol} \mathrm{mol}^{-1}$. Detection limit was $0.5 \mathrm{nmol} \mathrm{mol}^{-1}(2 \sigma, 1 \mathrm{~min})$ and total uncertainty was estimated to be $4 \% \pm 1 \mathrm{nmol} \mathrm{mol}^{-1}$.

The average sensitivity over the measurement period was $5.4 \times 10^{-3}$ (standard deviation, $\pm 6.5 \times 10^{-4}$ ) volts per nmol $\mathrm{mol}^{-1}$ ozone. The detection limit for ozone was calculated to be $<0.01 \mathrm{nmol} \mathrm{mol}^{-1}(2 \sigma, 2 \mathrm{~min})$. Periodically, the detector response was determined between 0 and $120 \mathrm{nmol} \mathrm{mol}^{-1}$, and was found to be linear $\left(r^{2}=0.998\right)$.

To determine the ozone-free instrument background, the sample was diverted through the ZV. Operation in this mode allowed a determination of the photomultiplier signal due to thermal electrons and other luminescence sources, and the signal was essentially equal to that of the PMT dark current.

The sequence for ambient measurements (M mode) consisted of a primary sequence loop of $1800 \mathrm{~s}(0.5 \mathrm{~h})$ duration. During the first and last $60 \mathrm{~s}$ of each half hour the sample was diverted through the ZV to provide background measurements ( $\mathrm{Z}$ mode), which were interpolated linearly across the remainder of the half hour. Ozone mixing ratios were determined as follows:

$$
\chi_{O 3}=\frac{\text { M mode detector signal (volts })- \text { interpolated } \mathrm{Z} \text { mode detector signal (volts) }}{\text { Sensitivity }\left(\text { volts } /\left(\mathrm{nmol} \mathrm{mol}^{-1}\right)\right)}
$$

Overall uncertainty was determined to $4.8 \% \pm 0.3 \mathrm{nmol} \mathrm{mol}^{-1}$.

Due to the efficient quenching of the excited state $\mathrm{NO}_{2}$ by collision with $\mathrm{H}_{2} \mathrm{O}$ molecules, the sensitivity of the chemiluminescence ozone detector changes as the water vapour content of the sample flow changes. However, during these measurements, the ambient water vapour did not change rapidly on time scales significantly shorter than the half-hour reporting interval. Therefore this effect was accounted for by each half-hour sensitivity determined by using the continuous ozone mixing ratio measured by the TEI 49C.

The sequence for ambient measurements consisted of a primary sequence loop of $1800 \mathrm{~s}(0.5 \mathrm{hr})$ duration. During the first and last $60 \mathrm{~s}$ of each half hour the sample was diverted through the ozone catalyst to provide background measurements, which were interpolated linearly across the remainder of the half hour.

\subsection{Eddy covariance fluxes}

Eddy covariance flux measurement requires a species detector, in concert with a sonic anemometer, to measure the vertical wind velocity $(w)$ and species concentration $(c)$ as instantaneous deviations from a longer-term mean. The derivation of the flux calculation is detailed elsewhere (Stull, 1988; Kaimal and Finnigan, 1994) and the end result is:

$\overline{w^{\prime} c^{\prime}}=$ flux,

where the prime (') indicates fluctuations from the mean and the overbar indicates an average over the time period. 


\subsection{Stomatal and non-stomatal conductances}

Conductances of the bulk forest canopy were determined using a resistance analog model of gas transfer, with turbulent $\left(R_{\mathrm{a}}\right)$, boundary layer $\left(R_{\mathrm{b}}\right)$, and surface (or canopy) $\left(R_{\mathrm{c}}\right)$ resistances in series, and the surface resistance consisting of stomatal $\left(R_{\mathrm{s}}\right)$ and non-stomatal $\left(R_{\mathrm{ns}}\right)$ resistances in parallel. The model does not separate fluxes to/from soil, stem and foliage.

$R_{\mathrm{tot}}=R_{\mathrm{a}}+R_{\mathrm{b}}+R_{\mathrm{c}}=R_{\mathrm{a}}+R_{\mathrm{b}}+\frac{R_{\mathrm{s}} R_{\mathrm{ns}}}{R_{\mathrm{s}}+R_{\mathrm{ns}}}$

Turbulence layer aerodynamic conductance, $g_{\mathrm{a}}$, was determined from measurements of wind speed at measurement height, $u(z)$, and friction velocity, $u^{*}$ (Monteith and Unsworth, 1990):

$g_{\mathrm{a}}=\frac{1}{R_{\mathrm{a}}}=\frac{u^{*^{2}}}{\overline{u(z)}}$

It represents the conductance of a parcel of air from height $z$ to $z_{0}+d$, where $z$ is the measurement height, $z_{0}$ is the roughness length and $d$ is the zero plane displacement. The laminar boundary layer conductance, $g_{\mathrm{b}}$, integrated for the entire canopy was determined according to (Choudhury and Monteith, 1988):

$g_{\mathrm{b}}=\left(\frac{2 a}{\alpha^{\prime}}\right) \sqrt{\left(\frac{u(h)}{0.7 w}\right)}\left[1-\exp \left(\frac{-\alpha^{\prime}}{2}\right)\right] \cdot L A I$

where $a=0.206 \mathrm{~mol} \mathrm{~m}^{-2} \mathrm{~s}^{-1}$ for water vapour and $a=0.378$ mol m${ }^{-2} \mathrm{~s}^{-1}$ for heat (Campbell and Norman, 1998), $\alpha^{\prime}=2.5$ is the attenuation coefficient for wind speed inside the canopy (Baldocchi et al., 1999), $w=0.08 \mathrm{~m}$ is average leaf width, $\mathrm{LAI}=$ $4 \mathrm{~m}^{2} \mathrm{~m}^{-2}$ is leaf area index, and $u(h)$ is wind speed at the top of the canopy. $u(h)$ was modelled from $u(z)$ correcting for diabatic conditions (Campbell and Norman, 1998).

Canopy temperature, $T_{\mathrm{c}}$, was estimated from sensible heat flux $(H)$ and air temperature at measurement height $\left(T_{\mathrm{a}}\right)$.

$T_{\mathrm{c}}=\frac{H}{c_{\mathrm{p}}}\left(\frac{g_{\mathrm{a}}+g_{\mathrm{b}}}{g_{\mathrm{a}} g_{\mathrm{b}}}\right)+T_{\mathrm{a}}$,

where $c_{\mathrm{p}}$ is the specific heat of air at constant pressure (Campbell and Norman, 1998).

Total conductance for water vapour $\left(g_{\text {tot_H2O }}\right)$ was then computed from water flux, air pressure, and leaf-to-air vapour pressure deficit $\left(\mathrm{VPD}_{\mathrm{a}}\right)$ (Campbell and Norman, 1998). Assuming that the non-stomatal conductance for water vapour is negligible, the stomatal conductance equals canopy conductance for water vapour, $g_{\text {s_H2O }}=g_{\text {c_H2O }}$, and can be calculated according to the inverse of the resistance from eq. (4). This assumption that water loss is predominately stomatal is a reasonable assumption for dry canopies, since forest floor evapotranspiration typically contributes less than $10 \%$ of total latent heat flux for deciduous forests during most of the growing season (Kelliher et al., 1992; Moore et al., 1996; Wilson et al., 2001) and only a proportion of this forest floor water flux is non-stomatal. Cuticular and peridermal transpiration accounts for only a couple of percent of maximum tree transpiration (Larcher, 2003) and therefore contributes very little to total latent heat flux in our ecosystem. Data during wet and humid conditions as well as conditions with low wind speed were treated as described in Section 2.5.

Total canopy conductance for ozone, $g_{\text {tot_O3 }}$, was calculated by dividing ozone flux $\left(F_{\mathrm{O} 3}\right)$ with the ozone mixing ratio.

Total canopy surface conductance for ozone $\left(g_{\mathrm{c} \_ \text {O } 3}\right)$ was solved according to the inverse of the resistance from eq. (4). The non-stomatal conductance for ozone, $g_{\text {ns_O3 }}$, was calculated as the difference between total canopy and stomatal conductance for ozone:

$g_{\text {ns } \_\mathrm{O}_{3}}=g_{\text {c_ } \mathrm{O}_{3}}-g_{\text {s_-O }}$

$g_{\mathrm{b} \_\mathrm{H} 2 \mathrm{O}}$ and $g_{\mathrm{s} \_\mathrm{H} 2 \mathrm{O}}$ were converted to $g_{\mathrm{b} \_\mathrm{O} 3}$ and $g_{\mathrm{s} \_\mathrm{O} 3}$ via the ratio of their molecular diffusivities (Campbell and Norman, 1998). In the following, $g_{\text {ns_O3 }}$ is denoted as $g_{\text {ns }}$.

\subsection{Analysis of data}

Sensible heat flux, latent heat flux, and $u^{*}$ were calculated in a parallel study by Pressley et al. (2005). Ozone fluxes for each half-hour period were calculated using the same method. Data were logged at $10 \mathrm{~Hz}$ on a computer running data acquisition software for a coincident isoprene flux measurement. Ozone detector counts were converted into an analogue voltage and recorded by the computer. Raw $10 \mathrm{~Hz}$ data were converted from a digital signal to scientific units. Corrections were made for the lag time between sample intake and detector by correlating the vertical wind component with the ozone mixing ratio. Hard spikes, which included instrumentation error and weather event interference, were removed. Wind coordinates were rotated so that $u$ was the mean wind direction and to account for non-zero mean vertical velocities (for instance, during nocturnal drainage or subsidence of the atmospheric boundary layer). A recursive filter with a 3min running mean was used to determine means and standard deviations. Soft spikes were removed from the vertical component of the wind speed. Half-hour means were subtracted from each data point to determine $w^{\prime}$ and $c^{\prime}$. Instantaneous fluxes $\left(w^{\prime} c^{\prime}\right)$ were calculated, taking into account the lag time. Half-hour average flux was determined.

Pressley et al. (2005) discusses and reports an overall flux uncertainty for this eddy covariance configuration to be on the order of $40 \%$. This is based on uncertainties associated with each measurement as well as the assumptions made when using the eddy covariance technique.

A wind speed filter was applied and data were not reported when $u(z)$ was less than $0.3 \mathrm{~m} / \mathrm{s}$. This affected less than $1 \%$ of the data set. A $u^{*}(z)$ filter was applied and data were not reported when $u^{*}$ was less than $0.3 \mathrm{~m} / \mathrm{s}$. This represented approximately $40 \%$ of the data, mostly during nighttime, when eddy covariance assumptions are often not met (see Goulden et al., 1996; Schmid et al., 2003). Modeled $u(h)$ was not allowed to fall below $0.3 \mathrm{~ms}^{-1}$ if $u(z)$ and $u^{*}(z)$ criteria were met. Data during pe- 
riods of rain were also excluded from the analysis. A relative humidity (RH) filter was applied, and $g_{\mathrm{s}}$ and $g_{\mathrm{ns}}$ were not reported when $\mathrm{RH}>90 \%$. This removed an additional $1.3 \%$ of the data that was not eliminated by the $u(z), u^{*}(z)$, and rain filters.

If realistic nighttime $g_{\mathrm{s}_{-} \mathrm{H}_{2} \mathrm{O}}$ data were unavailable (due to $u, u^{*}$, $\mathrm{RH}$ or rain filters or lacking or negative (downward) water flux data) (2000-0700 h local time), $g_{\mathrm{s}}$ was set to $0.018 \mathrm{~mol} \mathrm{~m}^{-2} \mathrm{~s}^{-1}$, the mean $g_{\mathrm{s}}$ value $(S E \pm 0.002)$ found for the period 2200$2400 \mathrm{hr}$ when reliable data were available. This substitution occurred for $75 \%$ of the night-time data, and is reasonable since darkness is a strong signal for stomatal closure.

Since calculated $g_{\mathrm{c}_{-} \mathrm{O}_{3}}$ are unreliable when $\left(R_{\mathrm{a}}+R_{\mathrm{b}}\right)$ and $R_{\text {tot }}$ are very similar, $g_{\text {c_- }{ }_{3}}$ was not reported when $R_{\text {tot }} /\left(R_{\mathrm{a}}+R_{\mathrm{b}}\right)$ was smaller than 1.25. This caused the elimination of only 27 data points.

\section{Results and discussion}

Few studies have partitioned ozone fluxes between stomatal and non-stomatal components in temperate deciduous forests, despite the predominance of this type in mid-latitude regions where ozone exposure can be elevated above background (USDA Forest Service, 2001). Here we contribute estimates of these flux components along with an analysis of their environmental dependencies in the mixed deciduous forest vis-àvis expected environmental responses of plant stomata (Jones, 1992; Lloyd et al., 1995) and surfaces (Grantz et al., 1995; Fowler et al., 1999). This forest has been well-characterized in terms of the $\mathrm{CO}_{2}$ and water vapour fluxes in previous work (Schmid et al., 2003; Bovard et al., 2005; Curtis et al., 2005).

\subsection{Overview of the forest ecosystem}

Fig. 2 shows the time series from June 27 to September 28, 2002, describing major environmental parameters and fluxes for the 2002 summer season. Each data point represents a 30-min average. During the summer of 2002, rainfall and temperature were relatively typical of the long-term record for the area, as was volumetric soil moisture to $30 \mathrm{~cm}$, except for the month of September, when it remained below $10 \%$ for the first $21 \mathrm{~d}$. Summertime ozone concentrations typically ranged from 30 to $60 \mathrm{nmol} \mathrm{mol}^{-1}$ with a few events near $100 \mathrm{nmol} \mathrm{mol}^{-1}$ as is typical in this region during summer. Ozone flux was strongly diurnal with maximum flux in the middle of the day of around 50-100 $\mu \mathrm{mol} \mathrm{m}^{-2} \mathrm{~h}^{-1}$ and nighttime flux at or near zero (Fig. 2, $n=3723$ ). Periodic short gaps in reported ozone flux occurred during instrument calibrations, or when eddy covariance assumptions were not met. The diurnal behaviour and magnitude of the ozone flux is consistent with data reported for deciduous canopies (e.g. Munger et al., 1996; Finkelstein et al., 2000) and coniferous canopies (e.g. Coe et al., 1995; Bauer et al., 2000; Finkelstein et al., 2000; Zeller and Nikolov, 2000; Kurpius et al., 2002; Kurpius and Goldstein, 2003; Goldstein et al., 2004; Mikkelsen et al., 2004; Gerosa et al., 2005) (Table 1).

Canopy stomatal conductance $(n=1404)$ was determined for this data set (excepting the period July 8-August 6 , when the IRGA was not functioning), and showed expected patterns of behaviour with respect to environmental drivers PPFD and VPD (Jones, 1992; Lloyd et al., 1995). Stomata opened with increasing light and closed with increasing VPD and temperature, patterns illustrated with grey lines in Figure $3 b$, d and f. Responses to

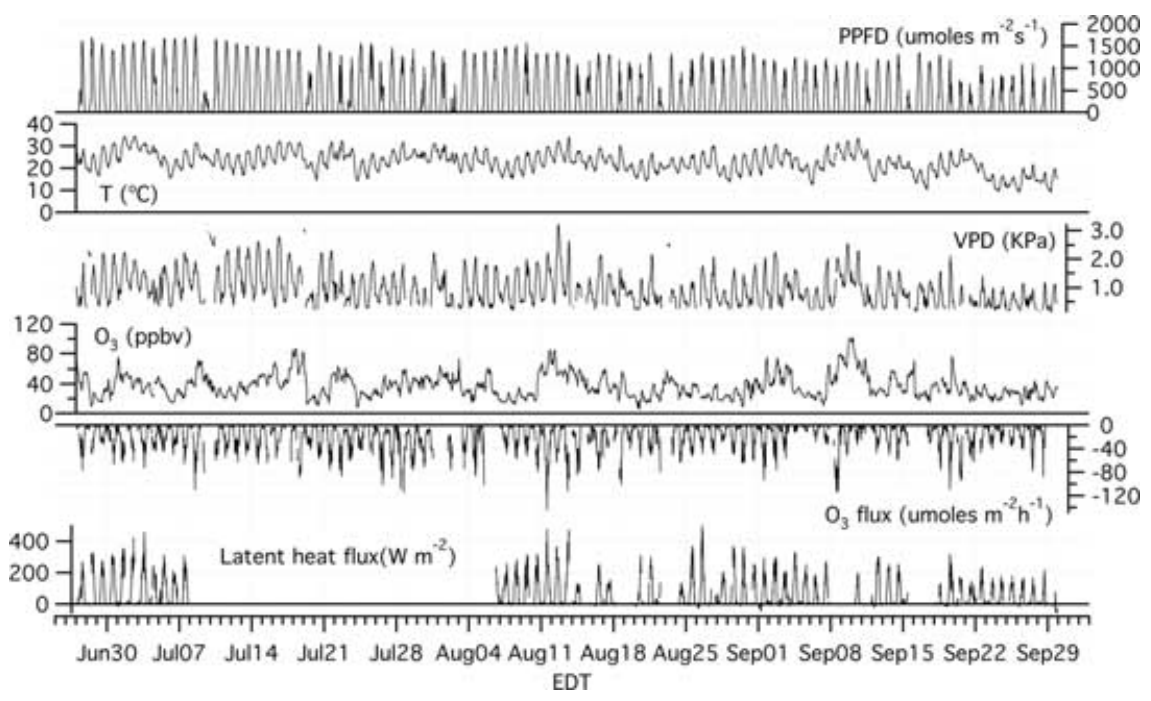

Fig. 2. Description of environmental conditions and fluxes for the northern deciduous forest in MI, USA for the 2002 measurement period. Shown are time series of photosynthetic photon flux density (PPFD), temperature ( $T$ ), vapour pressure deficit (VPD), ozone mixing ratio, ozone flux, and latent heat flux. The time axis is in local time, eastern daylight-savings time (EDT), four hours behind GMT. 
Table 1. Selection of recent estimates of ozone fluxes for various forest sites. The dominant tree species is indicated $(\mathrm{C}=$ conifer, $\mathrm{D}=\mathrm{deciduous,}$ $\mathrm{E}=$ evergreen non-conifer). Flux $(F)$ is reported per unit ground. Fluxes originally reported in ppb m s $\mathrm{m}^{-1} \mu \mathrm{g} \mathrm{m}^{-2} \mathrm{~s}^{-1}$ are converted to $\mu$ mol $\mathrm{m}^{-2}$ $\mathrm{h}^{-1}$ assuming $25^{\circ} \mathrm{C}$ and $101.3 \mathrm{kPa}$ atmospheric pressure.

\begin{tabular}{|c|c|c|c|c|}
\hline Dominant tree & $\begin{array}{l}\text { Location } \\
\text { (Lat. Long.) }\end{array}$ & $\begin{array}{l}\text { Maximum } F_{\text {day }} \\
\left(\mu \mathrm{mol} \mathrm{O} \mathrm{m}^{-2} \mathrm{~h}^{-1}\right)\end{array}$ & $\begin{array}{l}\text { Minimum } F_{\text {night }} \\
\left(\mu \mathrm{mol} \mathrm{O} \mathrm{m}^{-2} \mathrm{~h}^{-1}\right)\end{array}$ & References \\
\hline Pinus ponderosa $(\mathrm{C})$ & $38^{\circ} 53^{\prime} \mathrm{N}, 120^{\circ} 37^{\prime} \mathrm{W}$ & 80 & $\sim 0-5$ & $\begin{array}{l}\text { Bauer et al. 2000, Kurpius and } \\
\text { Goldstein 2003, Goldstein et al. } 2004\end{array}$ \\
\hline Picea sitchensis $(\mathrm{C})$ & $55^{\circ} 20^{\prime} \mathrm{N}, 3^{\circ} 26^{\prime} \mathrm{W}$ & 113 & 15 & Coe et al. 1995 \\
\hline Pinus taeda $(\mathrm{C})$ & $35^{\circ} 58^{\prime} \mathrm{N}, 79^{\circ} 7^{\prime} \mathrm{W}$ & 53 & 8 & Finkelstein, et al. 2000 \\
\hline Picea abies $(\mathrm{C})$ & $56^{\circ} 17^{\prime} \mathrm{N}, 8^{\circ} 25^{\prime} \mathrm{E}$ & 58 & 31 & Mikkelsen et al. 2000, 2004 \\
\hline Picea engelmanni $(\mathrm{C})$ & $41^{\circ} 22^{\prime} \mathrm{N}, 106^{\circ} 14^{\prime} \mathrm{W}$ & 53 & 8 & Zeller and Nikolov 2000 \\
\hline Quercus ilex $(\mathrm{E})$ & $41^{\circ} 44^{\prime} \mathrm{N}, 12^{\circ} 25^{\prime} \mathrm{E}$ & 184 & 0.4 & Gerosa et al. 2005 \\
\hline Prunus serotina/Pinus strobus (D/C) & $43^{\circ} 33^{\prime} \mathrm{N}, 75^{\circ} 14^{\prime} \mathrm{W}$ & 43 & 10 & Finkelstein, et al. 2000 \\
\hline Quercus rubra/Acer rubrum (D) & $42^{\circ} 32^{\prime} \mathrm{N}, 72^{\circ} 11^{\prime} \mathrm{W}$ & 40 & $\sim 0-4$ & Munger, et al. 1996 \\
\hline Populus grandidentata $(\mathrm{D})$ & $45^{\circ} 30^{\prime} \mathrm{N}, 84^{\circ} 42^{\prime} \mathrm{W}$ & 115 & 0 & This study \\
\hline
\end{tabular}

Fig. 3. Binned averages for environmental conductance $\left(g_{\mathrm{ns}}\right.$ and $\left.g_{\mathrm{s}}\right)$ responses for the northern deciduous forest during 2002: $g_{\text {ns }}$ versus PPFD (a), $g_{\mathrm{s}}$ versus PPFD (b), $g_{\mathrm{ns}}$ versus $T_{a}(\mathrm{c}), g_{\mathrm{s}}$ versus $T_{a}(\mathrm{~d}), g_{\mathrm{ns}}$ versus $\mathrm{VPD}_{\mathrm{a}}(\mathrm{e})$ and $g_{\mathrm{s}}$ versus $\mathrm{VPD}_{\mathrm{a}}$ (f). Data where PPFD was lower than $500 \mu \mathrm{mol} \mathrm{m}^{-2}$ $\mathrm{s}^{-2}$ were not used in relationships with $T_{a}$ and $\mathrm{VPD}_{\mathrm{a}}(\mathrm{c}-\mathrm{f})$. Error bars indicate standard error of the mean. The grey lines indicate trends of a priori hypothesized conductance responses to environmental factors based on expected patterns (Jones, 1992) and models (Jones, 1992; Grantz et al., 1995; Lloyd et al., 1995), with the magnitude scaled to the maximum conductances we observed. Two possible hypotheses with respect to $g_{\mathrm{ns}}$ and $T_{a}$ in (c) show a monotonic increase as per an Arrhenius-type function (solid line) and a thermal deactivation function (dashed line).
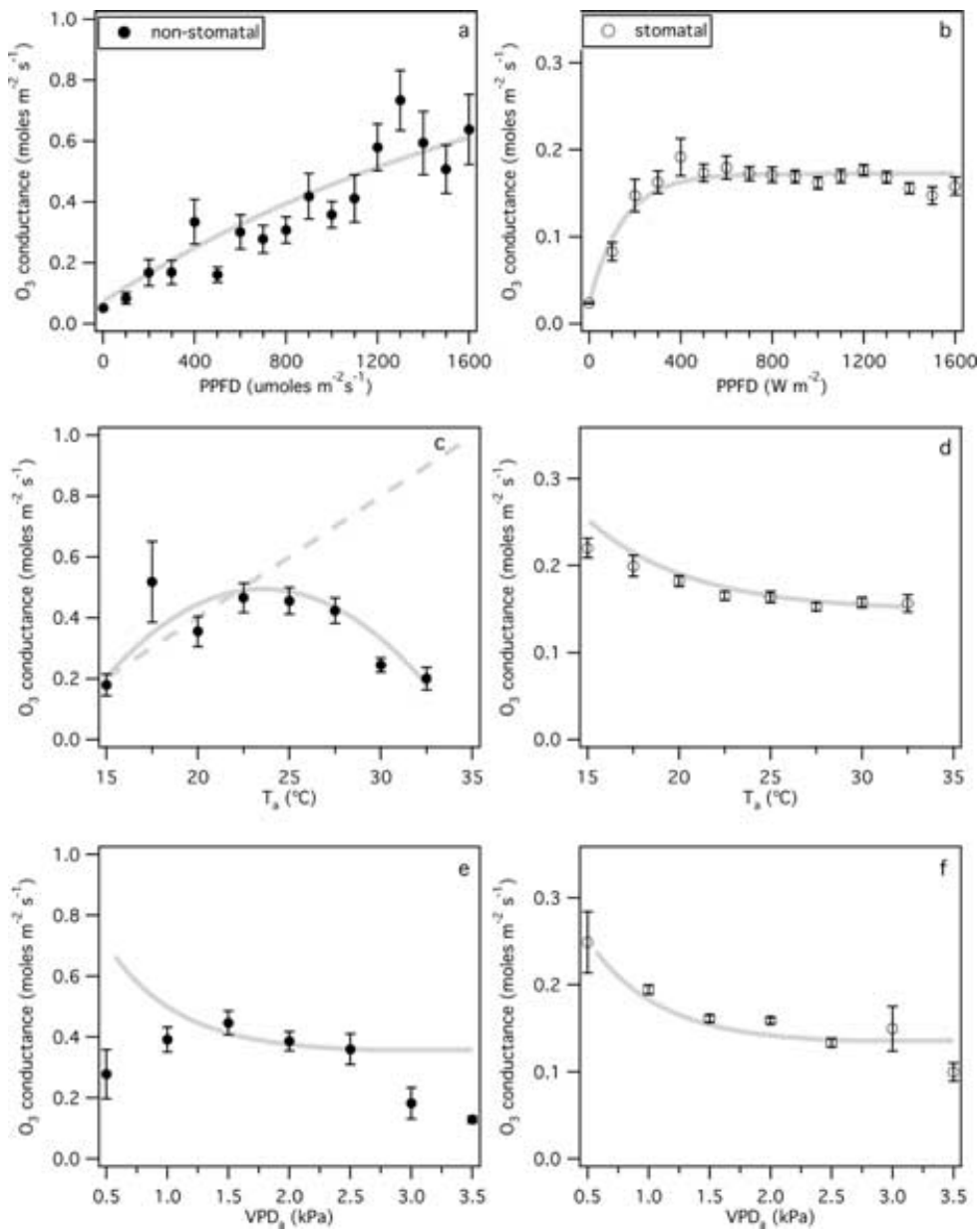

temperature and VPD could not be separated from one another, since these two variables were also highly correlated. The responses to PPFD and VPD, as well as the magnitude of $g_{\mathrm{s}}$, were within the range typically observed for this type of forest (Jones, 1992; Körner, 1994; Bovard et al., 2005).

\subsection{Partitioning of conductances and fluxes}

Given the environmental responses of stomata and the increase in PPFD in the morning and the decrease in temperature and VPD later in the day, the diurnal pattern of $g_{s}$ varied throughout 


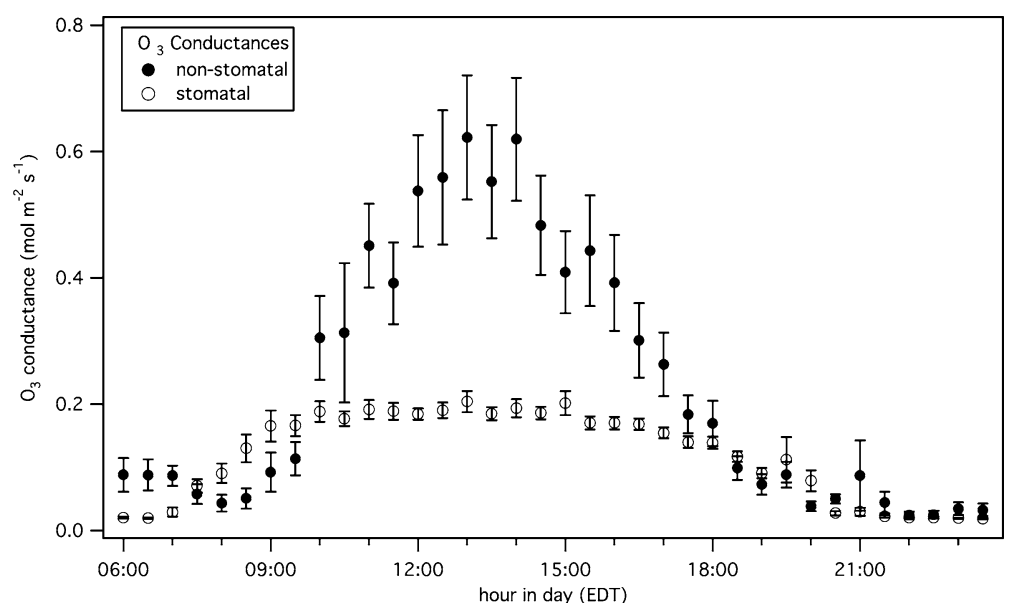

Fig. 4. Ensemble diurnal (0600-2400 h) course of half-hour binned averages for $g_{\mathrm{ns}}$ and $g_{\mathrm{s}}$. At night, both conductances were low and near the same order, with $g_{\mathrm{s}}$ between 0.01 and $0.03 \mathrm{~mol} \mathrm{~m}^{-2} \mathrm{~s}^{-1}$ and with $g_{\mathrm{ns}}$ between 0.01 and $0.05 \mathrm{~mol} \mathrm{~m}^{-2} \mathrm{~s}^{-1}$. Error bars indicate standard error of the mean.

the day (Fig. 4). $g_{\mathrm{ns}}(n=1228)$ varied to an even greater extent during daytime hours, which resulted in large variation in partitioning between stomatal and non-stomatal components. As the sun rose and set (from 0800 to $1000 \mathrm{~h}$ in the morning and from 1800 to $2100 \mathrm{~h}$ in the evening) $g_{\mathrm{s}}$ and $g_{\mathrm{ns}}$ tracked each other well. However, during periods of high light levels (1000 to $1800 \mathrm{~h}), g_{\text {ns }}$ increased to a peak at $1300 \mathrm{~h}$ and sharply decreased until $1800 \mathrm{~h}$, whereas $g_{\mathrm{s}}$ levelled off at $1000 \mathrm{~h}$ and remained relatively steady until $1800 \mathrm{~h}$. Average daytime $g_{\mathrm{c}}$ was $0.5 \mathrm{~mol} \mathrm{~m} \mathrm{~m}^{-2} \mathrm{~s}^{-1}$, which is higher than reported for evergreen forest ecosystems as summarized in Table 2. This is one of the first studies to estimate the magnitude of daytime ozone $g_{\mathrm{c}}$ for deciduous forests. However, leaf-level data suggest that stomatal fluxes and conductance are greater for deciduous trees than evergreens and conifers (Körner, 1994). Mean daytime (0800$2000 \mathrm{~h}) g_{\text {ns }}$ accounted for $66 \%$ of $g_{\mathrm{c}}$, whereas at night, both $g_{\text {ns }}$ and $g_{\mathrm{s}}$ were low and of the same order, between 0.01 and 0.05 mol m${ }^{-2} \mathrm{~s}^{-1}$. Given the higher average $g_{\mathrm{c}}$ but similar conductance ratios (both the daytime $g_{\mathrm{ns}}: g_{\mathrm{c}}$ ratio as well as the night:day $g_{\mathrm{c}}$ ratio) with a number of other studies in Table 2, this suggests that non-stomatal conductance for the aspen forest ecosystem was higher than for other forests.

We estimated a daily integrated stomatal ozone flux $\left(F_{\mathrm{O} 3}\right)$ by binning data by half-hour intervals over the measurement period (Fig. 5). The result was $2.7 \times 10^{5} \mathrm{nmol} \mathrm{m}^{-2}$ daily stomatal flux, roughly half the daily non-stomatal flux of $4.5 \times 10^{5} \mathrm{nmol}$ $\mathrm{m}^{-2}$. This finding of $63 \%$ non-stomatal flux is in accordance with other forest ecosystems (Table 2). However, it is clear that the non-stomatal ozone flux is neither constant between daytime and nighttime nor is it necessarily small in magnitude. Some studies estimate the diurnal ozone conductance assuming that nocturnal $g_{\text {ns }}$ applies to daytime (e.g. Mikkelsen et al., 2000). Other studies (e.g. Zeller and Nikolov, 2000) model $g_{\text {ns }}$ as constant and low, but our results disagree with this approach. Until consensus is reached, Emberson et al. (2000) recommends that models use a single value to represent $g_{\text {ns }}$, though better approximations should emerge from identifying environmental controls over $g_{\text {ns }}$. In order to estimate ozone sinks in forests, models should employ the dominant mechanisms responsible for stomatal and non-stomatal ozone conductances.

\subsection{Drivers for non-stomatal conductance}

Non-stomatal conductance for ozone increased monotonically with increasing PPFD (Fig. 3a), while it was highest in an intermediate range of $T_{\mathrm{a}}$ and significantly lower below $20^{\circ} \mathrm{C}$ and from $30{ }^{\circ} \mathrm{C}$ and above (Fig. 3c). The relationship between $g_{\text {ns }}$ and canopy temperature $\left(T_{\mathrm{c}}\right)$ had the same general shape, but was somewhat skewed to a higher $T$ range (not shown). As seen with $g_{\mathrm{s}}$, the relationships of $g_{n s}$ with $T_{\mathrm{a}}$ and VPD were similar (Fig. 3c and $3 \mathrm{e}$ ) since these two variables are highly correlated. Because $T_{\mathrm{a}}$ and PPFD are correlated, a subset of data was analysed where $T_{\mathrm{a}}$ did not have a strong effect on $g_{\text {ns }}\left(20-25^{\circ} \mathrm{C}\right)$. The PPFD $-g_{\text {ns }}$ relationship of the entire data set was reproduced for this subset (not shown). Similarly, the $T_{\mathrm{a}}-g_{\mathrm{ns}}$ relationship was confirmed looking at subsets of data where PPFD did not have a strong effect on $g_{\text {ns }}$ (not shown). Therefore, while most field studies do not separate responses driven by $T$ and PPFD (e.g. Coe et al., 1995; Fowler et al., 2001; Granat and Richter, 1995; Rondón et al., 1993) this study demonstrates evidence for independent and strong responses to both drivers.

The strong dependence of $g_{\text {ns }}$ on PPFD (e.g. light) is in agreement with laboratory findings by Rondón (1993), and supports the hypothesis that diurnal variation in $g_{\mathrm{ns}}$ is at least partly explained by ozone-destroying photochemical reactions at the leaf cuticle (Rondón, 1993; Rondón et al., 1993; Coe et al., 1995; Granat and Richter, 1995). Of course, it is also possible that the response of $g_{\text {ns }}$ to light is mediated by a biological process that is itself driven by light, such as light dependent emissions of biogenic VOCs (BVOCs) (Niinemets et al., 2004). Our study does not separate between these two effects.

The decrease in $g_{\text {ns }}$ at high $T$ is in conflict with the hypothesis that thermal degradation (dashed grey line in Fig. 3c) governs the variation in $g_{\mathrm{ns}}$ (Fowler et al., 2001). Instead, the $T_{\mathrm{a}}-g_{\mathrm{ns}}$ 


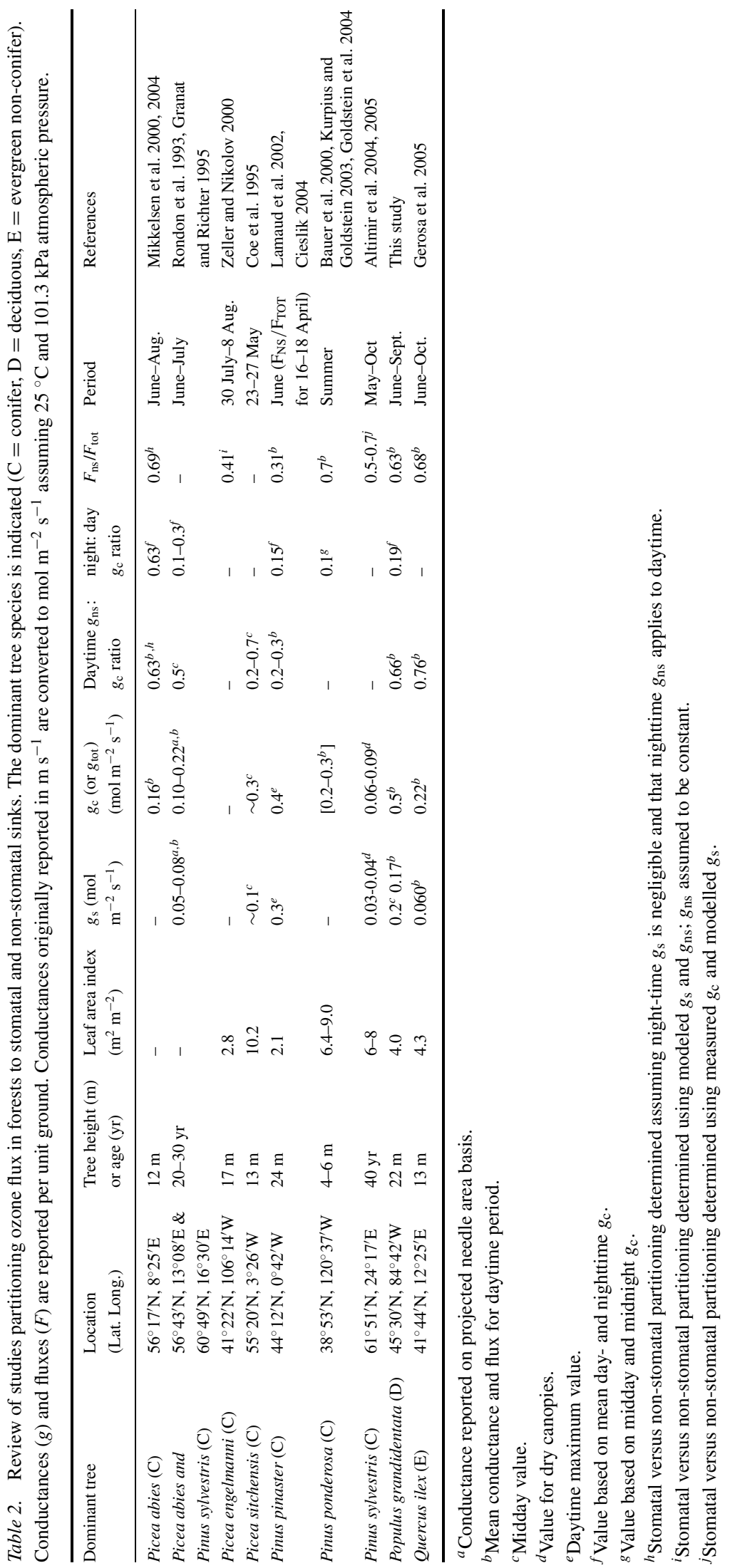




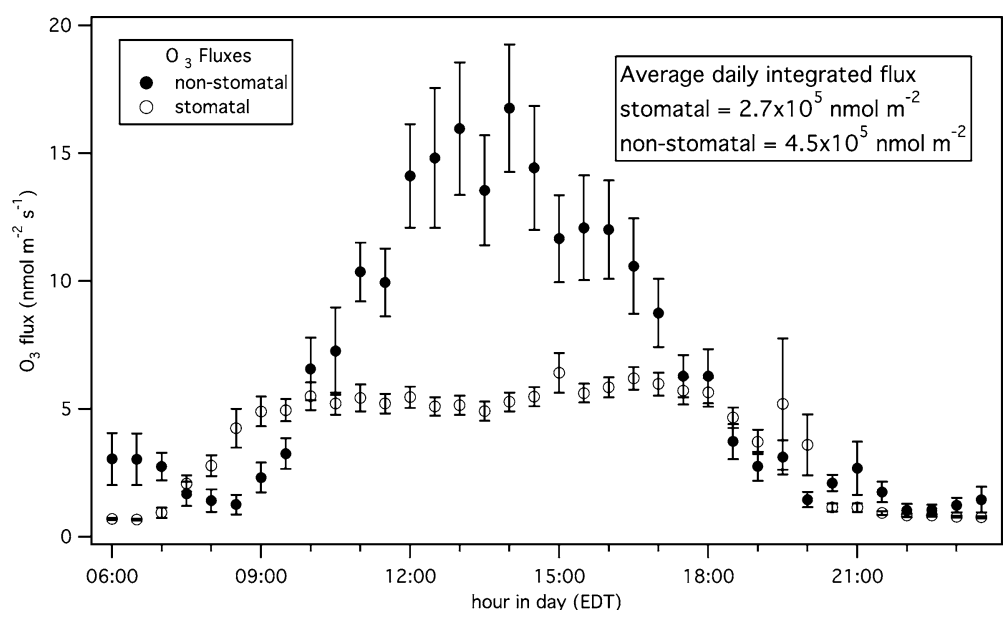

Fig. 5. Ensemble diurnal (0600-2400 h) course of half-hour binned averages for $F_{\mathrm{s}}$ and $F_{\mathrm{ns}}$. At night, fluxes were low and near the same order, with $F_{\mathrm{s}}$ just below $1 \mathrm{nmol}$ $\mathrm{m}^{-2} \mathrm{~s}^{-1}$ and $F_{\mathrm{ns}}$ between 1 and $2 \mathrm{nmol} \mathrm{m}^{-2}$ $\mathrm{s}^{-1}$. Error bars indicate standard error of the mean.

relationship suggests that a biological process with optimum $T_{\mathrm{a}}$ at $20-27^{\circ} \mathrm{C}\left(T_{\mathrm{c}} 26-31^{\circ} \mathrm{C}\right)$ is involved (solid grey line in Fig. $\left.3 \mathrm{c}\right)$. This behaviour draws an analogy to isoprene emission, which is correlated with light and heat, and falls once photosynthetic activity ceases, mirroring the temperature dependence of photosynthesis (Sharkey et al., 1991; Monson, et al., 1992; Kuzma and Fall, 1993). While isoprene would not react quickly enough with ozone to explain this behaviour (Paulson et al., 1992a,b), perhaps as-yet-unidentified BVOCs are emitted and are scavenging ozone. Increased non-stomatal ozone flux with increasing $T_{\mathrm{a}}$ was also reported for a Pinus ponderosa plantation, and this was attributed to the strong $T$ dependence of BVOC emissions (Goldstein et al., 2004; Kurpius and Goldstein, 2003). Although an exponential increase in ozone flux via gas-phase chemistry (matching the $T$ dependence of terpene emissions) was suggested in that study, data presented do not support an increase above $20{ }^{\circ} \mathrm{C}$ and do not go beyond $28{ }^{\circ} \mathrm{C}$ (Kurpius and Goldstein, 2003), where the decrease in $g_{\text {ns }}$ was found in the present study.

The increase in $g_{\text {ns }}$ at high relative humidity (grey line in Fig. 3e) seen in other studies (e.g. Zhang et al., 2002a; Altimir et al., 2004; Altimir et al., 2005) was not fully addressed by this study, where data with high relative humidity were excluded by conditions unfavourable to flux measurements, as well as an explicit RH filter. For the data that are included, a decrease in $g_{\text {ns }}$ was found at low VPD rather than an increase. The VPD $-g_{\text {ns }}$ relationship in Fig. 3e is for a subset of data where PPFD $>500$ $\mu \mathrm{mol} \mathrm{m} \mathrm{m}^{-2} \mathrm{~s}^{-1}$, in order to avoid confounding the VPD response with the PPFD response. As a consequence, data where VPD is lower than $0.5 \mathrm{kPa}$ are not included in Fig. 3e-f. Increased $g_{\text {ns }}$ for wet canopies has been demonstrated in numerous studies (e.g. Grantz et al., 1995; Pleijel et al., 1995; Zhang et al., 2002a; Altimir et al., 2005).

With flux measurements at one height only, this study cannot partition non-stomatal fluxes into reactions occurring at surfaces or in gas-phase. Kurpius and Goldstein (2003) suggested that gas-phase chemistry was the dominant ozone sink in a Pinus ponderosa plantation in the summer, being more than twice as strong as non-stomatal surfaces. However, their partitioning of non-stomatal surface fluxes was made using a model that assumes that the non-stomatal surface conductance was low and constant (Zeller and Nikolov, 2000). In a later experiment in the same ecosystem, Goldstein et al. (2004) reported that both monoterpene emissions and ecosystem ozone uptake increased dramatically after thinning, providing strong evidence that gasphase chemistry plays a major role in controlling ozone fluxes in forests emitting large quantities of BVOCs.

\section{Conclusions}

Light (PPFD) and temperature both influence non-stomatal conductance for ozone, and consequently the flux of ozone to a forest canopy. Total non-stomatal deposition represents, on average, $63 \%$ of the total flux. Ozone flux varies significantly over the course of the day, peaking at midday, and being at or near zero at night, so daytime non-stomatal ozone conductance should be estimated separately rather than by applying a night time value.

The data presented in this paper suggest that the assumption made by many models - that non-stomatal ozone conductance is constant and low - is untenable, and emphasizes the need for improvements in modelling the partitioning of ozone flux. While questions remain as to the mechanisms of non-stomatal conductance, it is important in the formulation of mechanistic models of ozone fluxes to quantify their magnitude and identify patterns with respect to major environmental factors in order to determine impacts of tropospheric ozone in forest ecosystems.

\section{Acknowledgments}

This research is part of the PROPHET program (NSF Award ATM 9505306) at the University of Michigan Biological Station and the Biosphere Atmosphere Research and Training (BART) program (NSF Award IGERT 9972803). It was supported in part by the Office of Science, U.S. Department of Energy, through the Midwestern Regional Center of the National Institute for 
Global Environmental Change under Cooperative agreement No. DE-FC03-90ER610100. We gratefully acknowledge the National Center for Atmospheric Research for construction of the UMMCI reaction vessels and University of Michigan Biological Station staff and administration, without whom this study would not have been possible.

\section{References}

Altimir, N., Kolari, P., Tuovinen, J. P., Vesala, T., Bäck, J., and co-authors. 2005. Foliage surface ozone deposition: a role for surface moisture? Biogeosciences Discussions 2, 1739-1793.

Altimir, N., Tuovinen, J. P., Vesala, T., Kulmala, M. and Hari, P. 2004. Measurements of ozone removal by Scots pine shoots: calibration of a stomatal uptake model including the non-stomatal component. Atmos. Environ. 38, 2387-2398.

Auble, D. L. and Meyers, T. P. 1992. an open path, fast response infraredabsorption gas analyzer for $\mathrm{H}_{2} \mathrm{O}$ and $\mathrm{CO}_{2}$. Boundary-Layer Meteorol. 59, 243-256.

Baldocchi, D. D., Fuentes, J. D., Bowling, D. R., Turnipseed, A. A. and Monson, R. K. 1999. Scaling isoprene fluxes from leaves to canopies: test cases over a boreal aspen and a mixed species temperate forest. $J$. Appl. Meteorol. 38, 885-898.

Bauer, M. R., Hultman, N. E., Panek, J. A. and Goldstein, A. H. 2000. Ozone deposition to a ponderosa pine plantation in the Sierra Nevada Mountains (CA): a comparison of two different climatic years. J. Geophys. Res.-Atmos. 105, 22123-22136.

Bovard, B. D., Curtis, P. S., Vogel, C. S., Su, H. B. and Schmid, H. P. 2005. Environmental controls on sap flow in a northern hardwood forest. Tree Physiol. 25, 31-38.

Campbell, G. S. and Norman, J. M. 1998. Introduction to Environmental Biophysics, Springer, New York.

Carroll, M. A., Bertman, S. B. and Shepson, P. B. 2001. Overview of the program for research on oxidants: photochemistry, emissions, and transport (PROPHET) summer 1998 measurements intensive. J Geophys. Res.-Atmos. 106, 24275-24288.

Choudhury, B. J. and Monteith, J. L. 1988. A 4-layer model for the heatbudget of homogeneous land surfaces. Quart. J. R. Met. Soc. 114, 373-398.

Cieslik, S. A. 2004. Ozone uptake by various surface types: a comparison between dose and exposure. Atmos. Environ. 38, 2409-2420.

Clough, P. N. and Thrush, B. A. 1967. Mechanism of chemiluminescent reaction between nitric oxide and ozone. Trans. Faraday Soc. 63, 915925.

Clyne, M. A. A. and Stedman, D. H. 1967. rate of recombination of nitrogen atoms. J. Phys. Chem. 71, 3071-3073.

Coe, H., Gallagher, M. W., Choularton, T. W. and Dore, C. 1995. Canopy scale measurements of stomatal and cuticular O-3 uptake by sitka spruce. Atmos. Environ. 29, 1413-1423.

Curtis, P. S., Vogel, C. S., Gough, C. M., Schmid, H. P., Su, H. B. and Bovard, B. D. 2005. Respiratory carbon losses and the carbon-use efficiency of a northern hardwood forest, 1999-2003. New Phytologist 167, 437-455.

Emberson, L., Simpson, D., Tuovinen, J. P., Ashmore, M. R. and Cambridge, H. M. 2000, Towards a modell of ozone deposition and stomatal uptake over Europe. (EMEP/MSC-W, Note 6/00), Research Note no. 42, DNMI, Oslo, Norway.
Felzer, B., Kicklighter, D., Melillo, J., Wang, C., Zhuang, Q., and co-authors. 2004. Effects of ozone on net primary production and carbon sequestration in the conterminous United States using a biogeochemistry model. Tellus 56B, 230-248.

Finkelstein, P. L., Ellestad, T. G., Clarke, J. F., Meyers, T. P., Schwede, D. B., and co-authors. 2000. Ozone and sulfur dioxide dry deposition to forests: observations and model evaluation. J. Geophys. Res.-Atmos. 105, 15365-15377.

Fowler, D., Cape, J. N., Coyle, M., Smith, R. I., Hjellbrekke, A. G., and co-authors. 1999. Modelling photochemical oxidant formation, transport, deposition and exposure of terrestrial ecosystems. Environ. Pollut. 100, 43-55.

Fowler, D., Flechard, C., Cape, J. N., Storeton-West, R. L. and Coyle, M. 2001. Measurements of ozone deposition to vegetation quantifying the flux, the stomatal and non-stomatal components. Water, Air, Soil Pollut. 130, 63-74.

Gerosa, G., Vitale, M., Finco, A., Manes, F., Denti, A. B., and co-authors 2005. Ozone uptake by an evergreen Mediterranean Forest (Quercus ilex) in Italy. Part I: micrometeorological flux measurements and flux partitioning. Atmos. Environ. 39, 3255-3266.

Goldstein, A. H., McKay, M., Kurpius, M. R., Schade, G. W., Lee, A. and co-authors. 2004. Forest thinning experiment confirms ozone deposition to forest canopy is dominated by reaction with biogenic VOCs. Geophys. Res. Lett. 31, Art. No. L22106.

Goulden, M. L., Munger, J. W., Fan, S. M., Daube, B. C. and Wofsy, S. C. 1996. Measurements of carbon sequestration by long-term eddy covariance: Methods and a critical evaluation of accuracy. Global Change Biol. 2, 169-182.

Granat, L. and Richter, A. 1995. Dry deposition to pine of sulfur-dioxide and ozone at low concentration. Atmos. Environ. 29, 1677-1683.

Grantz, D. A., Zhang, X. J., Massman, W. J., Denhartog, G., Neumann, H. H., and co-authors. 1995. Effects of stomatal conductance and surface wetness on ozone deposition in field-grown. Atmos. Environ. 29, 3189-3198.

Jones, H. G. 1992. Plants and Microclimate: A Quantitative Approach to Environmental Plant Physiology 2nd Edition., Cambridge University Press, Cambridge, 428 pp.

Kaimal, J. C. and Finnigan, J. J. 1994. Atmospheric Boundary Layer Flows : Their Structure And Measurement, Vol. XIII, Oxford University Press, New York 289 pp.

Karlsson, P. E., Uddling, J., Braun, S., Broadmeadow, M., Elvira, S., and co-authors. 2004. New critical levels for ozone effects on young trees based on AOT40 and simulated cumulative leaf uptake of ozone. Atmos. Environ. 38, 2283-2294.

Karnosky, D. F., Mankovska, B., Percy, K., Dickson, R. E., Podila, G. K., and co-authors. 1999. Effects of tropospheric O-3 on trembling aspen and interaction with CO-2: results from an O-3gradient and a face experiment. Water Air Soil Pollut. 116, 311322.

Karnosky, D. F., Percy, K. E., Xiang, B. X., Callan, B., Noormets, A. and co-authors. 2002. Interacting elevated CO-2 and tropospheric O-3 predisposes aspen (Populus tremuloides Michx.) to infection by rust (Melampsora medusae f. sp tremuloidae). Global Change Biol. 8, 329-338.

Karnosky, D. F., Zak, D. R., Pregitzer, K. S., Awmack, C. S., Bockheim, J. G., and co-authors. 2003. Tropospheric O-3 moderates responses of temperate hardwood forests to elevated CO-2: a synthesis of molecular 
to ecosystem results from the Aspen FACE project. Funct. Ecol. 17, 289-304.

Kelliher, F. M., Kostner, B. M. M., Hollinger, D. Y., Byers, J. N., Hunt, J. E., and co-authors. 1992. Evaporation, xylem sap flow, and tree transpiration in a new-zealand broad-leaved forest. Agric. Forest Meteorol. 62, 53-73.

Körner, C. 1994. Leaf diffusive conductances in the major vegetation types of the globe., In: Ecophysiology of Photosynthesis. Ecological studies 100, (ed. E. D. Schulze and M. M. Caldwell). Springer-Verlag, Berlin, 463-490.

Kurpius, M. R. and Goldstein, A. H. 2003. Gas-phase chemistry dominates O-3 loss to a forest, implying a source of aerosols and hydroxyl radicals to the atmosphere. Geophys. Res. Lett. 30, Art. No. 1371.

Kurpius, M. R., McKay, M. and Goldstein, A. H. 2002. Annual ozone deposition to a Sierra Nevada ponderosa pine plantation. Atmos. Environ. 36, 4503-4515.

Kuzma, J. and Fall, R. 1993. Leaf isoprene emission rate is dependent on leaf development and the level of isoprene synthase. Plant Physiol. 101, 435-440.

Lamaud, E., Carrara, A., Brunet, Y., Lopez, A. and Druilhet, A. 2002. Ozone fluxes above and within a pine forest canopy in dry and wet conditions. Atmos. Environ. 36, 77-88.

Larcher, W. 2003. Physiological Plant Ecology: Ecophysiology and Stress Physiology of Functional Groups, Springer, Berlin, New York, $513 \mathrm{pp}$.

Lloyd, J., Grace, J., Miranda, A. C., Meir, P., Wong, S. C., and co-authors. 1995. A Simple calibrated model of amazon rain-forest productivity based on leaf biochemical-properties. Plant Cell Environ. 18, 11291145 .

Massman, W. J. 2004. Toward an ozone standard to protect vegetation based on effective dose: a review of deposition resistances and a possible metric. Atmos. Environ. 38, 2323-2337.

Matyssek, R. and Sandermann, H. 2003. Impact of ozone on trees: an ecophysiological perspective., In: Progress in Botany, (ed.K. Esser, et al.). Springer Verlag Heidelberg, 349-404.

Mikkelsen, T. N. and Ro-Poulsen, H. 2002. In situ autumn ozone fumigation of mature Norway spruce - Effects on net photosynthesis. Phyton-Annales Rei Botanicae 42, 97-104.

Mikkelsen, T. N., Ro-Poulsen, H., Hovmand, M. F., Jensen, N. O., Pilegaard, K., and co-authors. 2004. Five-year measurements of ozone fluxes to a Danish Norway spruce canopy. Atmos. Environ. 38, 23612371.

Mikkelsen, T. N., Ro-Poulsen, H., Pilegaard, K., Hovmand, M. F., Jensen, N. O., and co-authors. 2000. Ozone uptake by an evergreen forest canopy: temporal variation and possible mechanisms. Environ. Pollut. 109, 423-429.

Monson, R. K., Jaeger, C. H., Adams, W. W., Driggers, E. M., Silver, G. M., and co-authors. 1992. Relationships among isoprene emission rate, photosynthesis, and isoprene synthase activity as influenced by temperature. Plant Physiol. 98, 1175-1180.

Monteith, J. L. and Unsworth, M. H. 1990. Principles of Environmental Physics, Edward Arnold, London, 291 pp.

Moody, J. L. and Samson, P. J. 1989. The influence of atmospheric transport on precipitation chemistry at 2 sites in the midwestern UnitedStates. Atmos. Environ. 23, 2117-2132.

Moore, K. E., Fitzjarrald, D. R., Sakai, R. K., Goulden, M. L., Munger, J. W., and co-authors. 1996. Seasonal variation in radiative and turbu- lent exchange at a deciduous forest in central Massachusetts. J. Appl. Meteorol. 35, 122-134.

Munger, J. W., Wofsy, S. C., Bakwin, P. S., Fan, S. M., Goulden, M. L., and co-authors. 1996. Atmospheric deposition of reactive nitrogen oxides and ozone in a temperate deciduous forest and a subarctic Woodland .1. Measurements and mechanisms. J. Geophys. Res.-Atmos. 101, 12639-12657.

Niinemets, U., Loreto, F. and Reichstein, M. 2004. Physiological and physicochemical controls on foliar volatile organic compound emissions. Trends Plant Sci. 9, 180-186.

Paulson, S. E., Flagan, R. C. and Seinfeld, J. H. 1992a. Atmospheric photooxidation of isoprene .1 . The hydroxyl radical and ground-state atomic oxygen reactions. Int. J. Chem. Kinetics 24, 79-101.

Paulson, S. E., Flagan, R. C. and Seinfeld, J. H. 1992b. Atmospheric Photooxidation of isoprene .2. The ozone-isoprene reaction. Int. J. Chem. Kinetics 24, 103-125.

Percy, K. E., Awmack, C. S., Lindroth, R. L., Kubiske, M. E., Kopper, B. J., and co-authors. 2002. Altered performance of forest pests under atmospheres enriched by $\mathrm{CO}_{2}$ and O-3. Nature 420, 403-407.

Percy, K. E., Legge, A. H. and Krupa, S. V. 2003. Tropospheric ozone: a continuing threat to global forests?., In: Air Pollution, Global Change and Forests in the New Millenium (ed. D. F. Karnosky, et al.). Elsevier Ltd., Oxford, 85-118.

Pleijel, H., Karlsson, G. P., Danielsson, H. and Sellden, G. 1995. Surface wetness enhances ozone deposition to a pasture canopy. Atmos. Environ. 29, 3391-3393.

Pressley, S., Lamb, B., Westberg, H., Flaherty, J., Chen, J., and co-authors. 2005. Long-term isoprene flux measurements above a northern hardwood forest. J. Geophys. Res.-Atmos. 110, Art. No. D07301.

Reich, P. B., Schoettle, A. W., Stroo, H. F., Troiano, J. and Amundson, R. G. 1987. Effects of ozone and acid-rain on white-pine (Pinus-Strobus) seedlings grown in 5 soils .1. Net photosynthesis and growth. Can. J. Bot.-Revue Canadienne De Botanique 65, 977-987.

Ridley, B. A., Grahek, F. E. and Walega, J. G. 1992. A small, highsensitivity, medium-response ozone detector suitable for measurements from light aircraft. J. Atmos. Ocean. Technol. 9, 142-148.

Rondón, A. 1993. Atmosphere-surface exchange of nitrogen oxides and ozone, Dissertation thesis, University of Stockholm, Stockholm, $115 \mathrm{pp}$.

Rondón, A., Johansson, C. and Granat, L. 1993. Dry deposition of nitrogen-dioxide and ozone to Coniferous forests. J. Geophys. Res.Atmos. 98, 5159-5172.

Schmid, H. P., Su, H. B., Vogel, C. S. and Curtis, P. S. 2003. Ecosystematmosphere exchange of carbon dioxide over a mixed hardwood forest in northern lower Michigan. J. Geophys. Res.-Atmos. 108, Art. No. 4417.

Sharkey, T. D., Loreto, F. and Delwiche, C. F. 1991. High-carbon dioxide and sun shade effects on isoprene emission from Oak and Aspen tree leaves. Plant Cell Environ. 14, 333-338.

Skärby, L., Ro-Poulsen, H., Wellburn, F. A. M. and Sheppard, L. J. 1998. Impacts of ozone on forests: a European perspective. New Phytologist 139, 109-122.

Statistics Canada 2002. 2001 Community Profiles. Statistics Canada Catalogue no. 93F0053XIE., Statistics Canada, Ottawa, Ontario.

Stull, R. B. 1988. An Introduction to Boundary Layer Meteorology, Kluwer Academic Publishers, Dordrecht, 670 pp. 
Thornberry, T., Carroll, M. A., Keeler, G. J., Sillman, S., Bertman, S. B., and co-authors. 2001. Observations of reactive oxidized nitrogen and speciation of NOy during the PROPHET summer 1998 intensive. J. Geophys. Res.-Atmos. 106, 24359-24386.

U. S. Census Bureau 2001. Census 2000 redistricting data (Public Law 94-171). Summary file 2000 Census of population and housing, U.S. Dept. of Commerce, Economics and Statistics Administration, U.S. Census Bureau, Washington, D.C.

Uddling, J., Gunthardt-Goerg, M. S., Matyssek, R., Oksanen, E., Pleijel, H., and co-authors. 2004. Biomass reduction of juvenile birch is more strongly related to stomatal uptake of ozone than to indices based on external exposure. Atmos. Environ. 38, 4709-4719.

USDA Forest Service 2001, Forest Inventory Analysis (FIA), USDA Forest Service, Washington, DC, USA.
Wilson, K. B., Hanson, P. J., Mulholland, P. J., Baldocchi, D. D. and Wullschleger, S. D. 2001. A comparison of methods for determining forest evapotranspiration and its components: sap-flow, soil water budget, eddy covariance and catchment water balance. Agric. Forest Meteorol. 106, 153-168.

Zeller, K. F. and Nikolov, N. T. 2000. Quantifying simultaneous fluxes of ozone, carbon dioxide and water vapour above a subalpine forest ecosystem. Environ. Pollut. 107, 1-20.

Zhang, L. M., Brook, J. R. and Vet, R. 2002a. On ozone dry deposition - with emphasis on non-stomatal uptake and wet canopies. Atmos. Environ. 36, 4787-4799.

Zhang, L. M., Moran, M. D., Makar, P. A., Brook, J. R. and Gong, S. L. 2002b. Modelling gaseous dry deposition in AURAMS: a unified regional air-quality modelling system. Atmos. Environ. 36, 537-560. 